\title{
GROWTH OF RAMIN (Gonystylus bancanus (Miq) Kurz.) PLANTATION ON VARIOUS PEAT SWAMP FORESTS IN INDONESIA
}

\author{
Tati Rostiwati $^{1,2}$, Murniati $^{3}$ and Hendromono ${ }^{1}$
}

\begin{abstract}
Ramin (Gonystylus bancanus (Miq) Kurz.) is a trade name of timber produced from a group of Gonystylus species. It is a well-known species because of its high timber quality and value. Ramin natural population has been decreasing sharply since the last two decades due to over exploitation, and nowadays leads to extinction. The objective of this research was to analyze the growth of ramin plantation on various sites. Data were collected from February to April 2005 through field survey on five sites of peat-swamp forest areas in four provinces, Riau, Jambi, West and Central Kalimantan. The result showed that ramin annual early growth varied across sites. It grew better on deep peat soil (3 - 4 $\mathrm{m}$ in depth) and under moderate shading (55-60\%) during early growth. The highest early height growth $(52.27 \mathrm{~cm} /$ year$)$ occurred at Sei Bakau, West Kalimantan. Whereas, it highest early diameter growth $(0.73 \mathrm{~cm} /$ year $)$ was found at Rokan Hilir, Riau. The characteristics of site are very important for a successful growth of ramin plantation, including peat depth and level of shading. Annual early growth of ramin as along in line with increasing of the plant age, namely a four- times increase of plant age (from 1.6 - 2 years to 6.5 - 7.3 years), the annual early height and diameter growth decreased until they reached a half and one third of the starting values. Since the growth of ramin is very slow, it is necessary to find and develop technologies to accelerate growth rate of the ramin plants. Application of mycorrhizal fungal inoculum is a promising technology, but their role in promoting ramin growth and the needed cost must be tested and analyzed under various conditions of the peat-swamp soils in Indonesia.
\end{abstract}

Keywords: Early growth, site characteristics, peat-swamp forest, peat depth, shading

\section{INTRODUCTION}

Gonystylus bancanus (Miq.) Kurz (ramin) is species with a medium-large trunk, measuring 40 to $45 \mathrm{~m}$ tall, up to $120 \mathrm{~cm}$ in diameter. The species natural distribution includes southwestern Peninsular Malaysia, south-eastern Sumatra, Bangka and Borneo (Soerianegara and Lemmens, 1994). Ramin grows in small groups of an association at lowland freshwater swamp or peat-swamp forests not affected by tidal waters but often found in broad belts along the coast. Most ramin forests are subject to periodic inundation, but the species is also found in non-inundated areas up to $100 \mathrm{~m}$ above sea level. Ramin forest is occasionally found in pure stands e.g. in Sarawak.

In the early 1980s, Indonesia is the largest exporter of ramin timber, especially sawnwood, accounting for $38 \%$ in volume and $46 \%$ in value of the total export, followed by

\footnotetext{
${ }^{1}$ Forest Plantation Research and Development Center, Jalan Gunung Batu No.5, Bogor

${ }^{2}$ Corresponding author. E-mail: rostiwati@yahoo.com

${ }^{3}$ Forest and Nature Conservation Research and Development Center, Jalan Gunung Batu No.5, Bogor
} 
Sarawak and Peninsular Malaysia. The average annual export was $598,000 \mathrm{~m}^{3}$ with a value of US $\$ 119$ million. In 1987, the export of sawn ramin was $299,000 \mathrm{~m}^{3}$ (with a value of US $\$ 86$ million) and in 1988 it was 224,000 $\mathrm{m}^{3}$ (with a value of US\$ 74 million) (Soerianegara and Lemmens, 1994).

Ramin natural population has been decreasing sharply since the last two decades due to over exploitation, and nowadays is leading to extinction. In order to protect the population of ramin in natural forests, a ban on ramin logging and trade was issued through the decree of Minister of Forestry No. 127/Kpts-IV/2001. It is meant to be a temporary stop of logging and trade of ramin, or called ramin moratorium. Only eco-label certified company is allowed to cut ramin trees and it should be recommended by Indonesian Institute of Science (Lembaga Ilmu Pengetahuan Indonesia/LIPI). In addition, ramin wood was included in Appendix II of the CITES (Anonimous, 2004).

Although ramin in natural peat-swamp forests nearly extincts, there has not been enough initiatives to develop ramin plantation yet. The lack of technical information is perhaps among the reasons. Research on silviculture of ramin was started by Alrasyid and Soerianegara in 1978. However, those researches were discontinued for about a decade, until it was initiated again around 1994. Istomo (1994) reported there was a significant correlation between existing of ramin in natural peat-swamp forest and thickness of the peat: the deeper the peat, furthermore ramin trees were found. Ramin trees were dominant at peat depth of 350 to $600 \mathrm{~cm}$. He indicated that the growth behaviour of ramin species was semi-tolerant, at seedling and sapling stages, they did not need much sunlight. However, at pole stage they need more sunlight and at tree stage they can receive full sunlight as the ramin canopy occupied stratum A of the forest canopy. This ramin behaviour implies that a silviculture treatment is needed at the pole stage to help ramins obtain canopy opening in the forest. This finding confirmed a previous study by Soediarto et al. (1963), who reported that ramin trees needed sunlight, even though they need shading at seedling stage.

This study may be perceived by a continuation of previous researches. The objective of this research was to analyze the growth of ramin plantation on various sites. The information obtained would be necessary for supporting development of ramin plantation across different sites in Indonesia.

\section{MATERIALS AND METHODS}

\section{A. Time and Location}

The research was carried out from February to April 2005. Direct observation was carried out in five sites (four provinces) of ramin plantations. Table 1 presents the five sites including it's characteristics.

\section{B. Research Method}

Height and diameter of young ramin trees were measured at the five sample plots of ramin plantations. The sampling intensity ranged from 3 to $33 \%$ of the ramin populations. 
The size of ramin population and the sampling intensity used at each site are presented in Table 1.

\section{Data Analysis}

Data analysis is mainly calculation of early growth. The formulas used are, as follows :

Early height growth $=$ peryear

Average height at measurement time - Average height of seedlings

Early diameter $=$ growth per year

Plant age (years)

Average diameter at measurement time - Average diameter of seedlings

Tabel 1. The size of ramin population and the sampling intensity at five sites

\begin{tabular}{|c|c|c|c|c|}
\hline No. & $\begin{array}{l}\text { Site and } \\
\text { Company/ } \\
\text { Institution }\end{array}$ & Site Chara & cteristic & $\begin{array}{c}\text { Size of } \\
\text { Population } \\
\text { (plants or ha) } \\
\text { and Sampling } \\
\text { Intensity } \% \text { ) }\end{array}$ \\
\hline 1 & $\begin{array}{l}\text { Rokan Hilir, } \\
\text { Riau } \\
\text { PT Diamond } \\
\text { Raya Timber } \\
\text { (PT. DRT) }\end{array}$ & $\begin{array}{l}\text { - Thickness of peat } \\
\text { - Level of periodic inundating } \\
\text { - Vegetation } \\
\text { - Light intensity } \\
\text { - Rainfall } \\
\text { - Altitude }\end{array}$ & $\begin{array}{l}: 3.5 \text { to } 5 \mathrm{~m} \\
: \quad 0 \text { to } 15 \mathrm{~cm} \\
: \text { secondary forest } \\
: \pm 60 \% \\
: 2637 \mathrm{~mm} / \text { year } \\
: \quad 2 \text { to } 25 \mathrm{~m} \text { asl }\end{array}$ & $\begin{array}{c}120 \text { plants } \\
33 \%\end{array}$ \\
\hline 2 & $\begin{array}{l}\text { Muara Jambi, } \\
\text { Jambi } \\
\text { PT Putraduta } \\
\text { Indah Wood } \\
\text { (PT. PIW) }\end{array}$ & $\begin{array}{l}\text { - Thickness of peat } \\
\text { - Level of periodic inundating } \\
\text { - Vegetation } \\
\text { - Light intensity } \\
\text { - Rainfall } \\
\text { - Altitude }\end{array}$ & $\begin{aligned}: & 2 \text { to } 6 \mathrm{~m} \\
: & 20 \mathrm{~cm} \\
: & \text { fern and alang-alang } \\
& \text { grass } \\
: & \pm 70 \% \\
: & 2000-2500 \mathrm{~mm} / \text { year } \\
: & 10-30 \mathrm{~m} \text { asl }\end{aligned}$ & $\begin{array}{l}6 \mathrm{ha} \\
3 \%\end{array}$ \\
\hline 3 & $\begin{array}{l}\text { Sei Bakau, } \\
\text { West } \\
\text { Kalimantan } \\
\text { Tanjungpura } \\
\text { University }\end{array}$ & $\begin{array}{l}\text { - Thickness of peat } \\
\text { - Level of periodic inundating } \\
\text { - Vegetation } \\
\text { - Light intensity } \\
\text { - Rainfall } \\
\text { - Altitude }\end{array}$ & $\begin{array}{l}: 0.6-4 \mathrm{~m} \\
: \quad 5 \text { to } 50 \mathrm{~cm} \\
: \text { secondary forest } \\
: \quad 55 \% \\
: 1100-3300 \mathrm{~mm} / \text { year } \\
: 10 \mathrm{~m} \text { asl }\end{array}$ & $\begin{array}{l}1.5 \mathrm{ha} \\
20 \%\end{array}$ \\
\hline 4 & $\begin{array}{l}\text { Mandor, West } \\
\text { Kalimantan } \\
\text { PT. Inhutani } \\
\text { II }\end{array}$ & $\begin{array}{l}\text { - Thickness of peat } \\
\text { - Level of periodic inundating } \\
\text { - Vegetation } \\
\text { - Light intensity } \\
\text { - Rainfall } \\
\text { - Altitude }\end{array}$ & $\begin{array}{l}: 0.6-1 \mathrm{~m} \\
: \quad 5-50 \mathrm{~cm} \\
: \text { shrubs } \\
: \quad \pm 50 \% \\
: \quad 3154 \mathrm{~mm} / \text { year } \\
: \quad 0.5 \mathrm{~m} \mathrm{asl}\end{array}$ & $\begin{array}{c}36 \text { plants } \\
22 \%\end{array}$ \\
\hline 5 & $\begin{array}{l}\text { Teluk Umpan, } \\
\text { Central } \\
\text { Kalimantan } \\
\text { BP2HT-IBB }\end{array}$ & $\begin{array}{l}\text { - Thickness of peat } \\
\text { - Level of periodic inundating } \\
\text { - Vegetation } \\
\text { - Light intensity } \\
\text { - Rainfall } \\
\text { - Altitude }\end{array}$ & $\begin{array}{l}:>5 \mathrm{~m} \\
: \quad 10-40 \mathrm{~cm} \\
: \quad \text { secondary forest } \\
: \quad \pm 40 \% \\
: \quad 780-2660 \mathrm{~mm} / \text { year } \\
: \quad 0-10 \mathrm{~m} \text { asl }\end{array}$ & $\begin{array}{c}150 \text { plants } \\
20 \%\end{array}$ \\
\hline
\end{tabular}




\section{RESULTS AND DISCUSSION}

\section{A. Results}

Growth behavior of ramin species is semi-tolerant and the trees tend to be dominant at deep peat soils. It indicates that the important site characteristics for ramin growth are light intensity and thickness of the peat. Hence, measured height and stem diameter of ramin plants as well as their increment per year at five sites are listed according to light intensities and thicknesses of the peat (Table 2).

Table 2. Average of actual height and stem diameter of ramin plants as well as their early growth per year at five sites

\begin{tabular}{|c|c|c|c|c|c|c|}
\hline \multirow{2}{*}{ Site } & \multirow[b]{2}{*}{$\begin{array}{l}\text { Plant Age } \\
\text { (years) }\end{array}$} & \multicolumn{2}{|c|}{ Site Characteristics } & \multirow[b]{2}{*}{ Strip } & \multicolumn{2}{|c|}{ Average } \\
\hline & & $\begin{array}{c}\text { Thickness } \\
\text { of peat } \\
(\mathrm{m})\end{array}$ & $\begin{array}{c}\text { Light } \\
\text { Intensity } \\
(\%)\end{array}$ & & $\begin{array}{l}\text { Height } \\
(\mathrm{cm})\end{array}$ & $\begin{array}{l}\text { Diameter } \\
(\mathrm{cm})\end{array}$ \\
\hline \multirow[t]{5}{*}{ Rokan Hilir, Riau } & 1.6 & $3.5-5$ & \pm 60 & 1 & 81.50 & 1.83 \\
\hline & & & & 2 & 82.63 & 1.68 \\
\hline & & & & 3 & 60.63 & 1.45 \\
\hline & & & & 4 & 70.75 & 1.22 \\
\hline & & & & 5 & 60.57 & 1.29 \\
\hline \multicolumn{4}{|c|}{ Annual Early Growth } & & 34.24 & 0.73 \\
\hline \multirow[t]{2}{*}{ Muara Jambi, Jambi } & 3.5 & $2-6$ & \pm 70 & 1 & 49.34 & 0.98 \\
\hline & & & & 2 & 38.71 & 0.91 \\
\hline \multicolumn{4}{|c|}{ Annual Early Growth } & & 2.58 & 0.13 \\
\hline \multirow{2}{*}{$\begin{array}{l}\text { Sei Bakau, West } \\
\text { Kalimantan }\end{array}$} & 2 & $0,6-4$ & $\pm 55 \%$ & & 141.13 & 1.536 \\
\hline & ual Early & rowth & & & 50.27 & 0.49 \\
\hline \multirow{3}{*}{$\begin{array}{l}\text { Mandor, West } \\
\text { Kalimantan } \\
\end{array}$} & 7.3 & $0,6-1$ & \pm 50 & & 160.19 & 2.125 \\
\hline & & & & & & \\
\hline & iual Early & rowth & & & 19.20 & 0.24 \\
\hline \multirow{4}{*}{$\begin{array}{l}\text { Teluk Umpan, } \\
\text { Central Kalimantan }\end{array}$} & 6.5 & $>6$ & \pm 40 & 1 & 149.00 & 0.910 \\
\hline & & & & 2 & 157.00 & 0.910 \\
\hline & & & & 3 & 228.00 & 1.640 \\
\hline & & & & 4 & 71.00 & 0.580 \\
\hline \multicolumn{4}{|c|}{ Annual Early Growth } & & 23.27 & 0.16 \\
\hline
\end{tabular}


Differences of height and diameter growth rate (annual early growth) of ramin plants among five sites are presented in Figure 1 and 2.

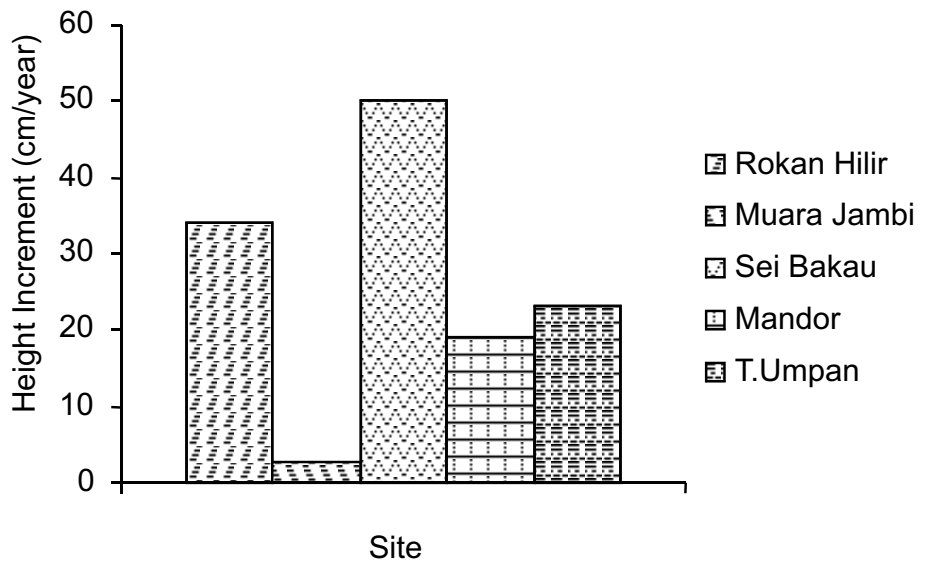

Figure 1. Annual early height growth of ramin plants on five sites (different thickness of peat and light intensity). Rokan Hilir (3.5 - $5 \mathrm{~m} ; 60 \%)$, Muara Jambi $(2-6 \mathrm{~m} ; 70 \%)$, Sei Bakau (0.6 - $4 \mathrm{~m} ; 55 \%)$, Mandor (0.6-1 m;50\%) and T. Umpan (>6 m; 40\%)

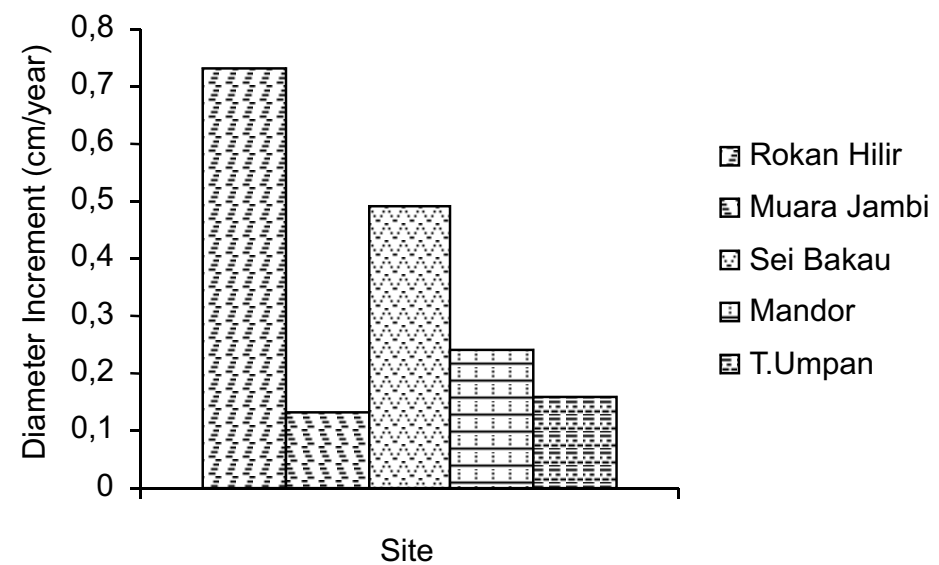

Figure 2. Annual early diameter growth of ramin plants on five sites (different thickness of peat and light intensity). Rokan Hilir (3.5 - $5 \mathrm{~m} ; 60 \%)$, Muara Jambi $(2-6 \mathrm{~m} ; 70 \%)$, Sei Bakau (0.6 - $4 \mathrm{~m} ; 55 \%)$, Mandor (0.6 - $1 \mathrm{~m} ; 50 \%)$ and T. Umpan (> $6 \mathrm{~m} ; 40 \%)$ 
The highest annual early height growth of ramin plants was found at Sei Bakau, West Kalimantan with 0.6 to $4 \mathrm{~m}$ of peat depth and $55 \%$ of light intensity, while the highest annual early diameter growth was showed by ramin plants growing on 3.5 to $5 \mathrm{~m}$ depth of peat and under $60 \%$ of light intensity at Rokan Hilir, Riau. It means that the height growth was faster under $55 \%$ light intensity than that under $60 \%$ of light intensity, and diameter growth was faster under $60 \%$ of light intensity compared to that under $55 \%$ of light intensity. The lowest annual increment, both height and diameter, of ramin plants was found at Muara Jambi with 2 to $6 \mathrm{~m}$ of peat depth and $70 \%$ of light intensity. The very young ramin planted at Rokan Hilir and Sei Bakau (1.6 to 2 years old) indicated that the growth was much faster (more or less two times) compared to ramin planted at Mandor and Teluk Umpan that were much older (6.5 to 7.3 years old). Ramin grew at Mandor and Teluk Umpan with very different peat depth (Mandor: 0.6 to $1 \mathrm{~m}$ and Teluk Umpan: $>6 \mathrm{~m}$ ) showed the most similar increment of height and diameter. Annual early height growth of ramin plants at Teluk Umpan with light intensity $40 \%$ was slightly higher than those found at Mandor with $50 \%$ of light intensity.

\section{B. Discussion}

The annual early height growth of ramin planted at four of these five study sites, ranging from 19.20 to $50.27 \mathrm{~cm}$, was higher than the annual height early growth of ramin reported in some previous studies. Soerianegara and Lemmens (1994) reported that the height growth of ramin planted from nursery seedlings were $12.4 \mathrm{~cm}$ per year, while Soerianegara et al. (1996) informed the early height growth of ramin planted on peat soil with depth 50 to 200 $\mathrm{cm}$ was $14.42 \mathrm{~cm}$ per year. The highest increments in natural condition may be because a sufficient light intensity received by the young plants. Other more recently studies on ramin growth are by Muin and Purwita (2002) and Muin (2004) that informed the annual height increment of ramin planted under moderate shading were $20.88 \mathrm{~cm}$ and $48.4 \mathrm{~cm}$, respectively. Compared to these reports, our findings showed a higher annual early growth values than those found by Muin and Purwita (2002), but only Sei Bakau ramin plantation had higher annual increment than those found by Muin (2004). The highest annual height increment of ramin planted at Sei Bakau compared to the other four study of this study and the other previous findings indicated an appropriate site characteristics, and intensive plantation maintenance. Bastoni (1999) and Bastoni and Sianturi (2000) suggested that horizontal liberation cutting should be done three times during the first year of ramin plantation. Further, Riyanto (1999) explained that the horizontal liberation cutting treatment showed a positive response to annual increment of ramin plants.

The annual early diameter growth of ramin planted at Rokan Hilir showed the highest value among all ramin plantation sites observed, followed by ramin plants at Sei Bakau. These annual diameter increments of ramin planted at the two different sites (Rokan Hilir and Sei Bakau) were higher than the other information available previously (Daryono, 1996; Muin and Purwita, 2002) except for report by Soerianegara et al. (1996). The annual diameter increment of ramin plants during their early growth reported by Soerianegara et al. (1996) was $1.81 \mathrm{~cm}$ at deeper peat $(100-200 \mathrm{~cm})$ and $0.94 \mathrm{~cm}$ at shallower peat $(50-100 \mathrm{~cm})$. However, they did not explain the light intensity of the experiment site.

Annual early growth, either height or diameter, of ramin planted along left and right side of the railway track of PT. PIW in Muara Jambi was very low (early height growth: $2.58 \mathrm{~cm}$ 
and early diameter growth: $0.13 \mathrm{~cm}$ per year). This annual growth was the lowest one compared to the other previous findings (Soerianegara and Lemmens, 1994; Daryono, 1996; Soerianegara et al., 1996; Muin and Purwita, 2002) and to this current study. This is assumed because the site was nearly full open area with undergrowth vegetation of fern and alangalang. The ramin plants were exposed to a high competition from these weed is due to no plantation maintenance at all. Previous research showed that ramin at early growth in the field needed moderate shade, because ramin is semi-tolerant species. When the height of ramin seedlings was less than $50 \mathrm{~cm}$, they needed moderate shading (between 35 and $65 \%$ ), however after the seedlings reached height of more than $50 \mathrm{~cm}$, vertical liberation by cutting of non-commercial trees and shrubs around seedlings may increase the growth of seedlings in the field (Muin and Purwita, 2002).

When the growth of ramin at Sei Bakau is compared to the growth of ramin at Mandor with nearly similar light intensity, it was clearly that the growth of ramin at Mandor was much lower than that of ramin at Sei Bakau. This perhaps is related mainly to the thickness of the peat, where at Sei Bakau site, the depth of the peat was 60 to $400 \mathrm{~cm}$, while at Mandor plantation it was less than $100 \mathrm{~cm}$.

In Teluk Umpan, Central Kalimantan, annual early height growth for 6.5 year old ramin plants was $23.27 \mathrm{~cm}$ and yearly diameter early growth was $0.16 \mathrm{~cm}$. Measurement at the same area when the ramin plants were 5 years old showed that the annual height increment was $20.01 \mathrm{~cm}$ and stem diameter increment was $0.27 \mathrm{~cm}$ (Daryono, 1996). Those two time series of data indicated that during period of fifth to sixth year of the ramin age, height growth was more dominant than diameter growth. This is caused by the need of the ramin plants to catch more sunlight at that stage and this in line with Soediarto et al. (1963) study that ramin trees needed sunlight although at seedling stage they needed shading.

Analysis of a data series on the annual early growth of ramin plants at four sites (Rokan Hilir, Sei Bakau, Mandor and Teluk Umpan) with different age ranging from 1.6 to 7.3 years indicated that the stage of growth has a tight correlation to the early growth of the ramin plants. Annual early growth of ramin is decreasing in line with the increasing of the plant age. The correlations are as follows.

By increasing of plant age four times (from 1.6 - 2 years to 6.5 - 7.3 years), the annual early height growth decreased until it reaches a half of the starting value (from average 42.25 $\mathrm{cm}$ to $21.24 \mathrm{~cm}$ )

By increasing of plant age four times (from 1.6 - 2 years to 6.5 - 7.3 years), the annual early diameter growth decreased to one third of the starting value (from average $0.61 \mathrm{~cm}$ to $0.22 \mathrm{~cm})$.

Based on the literature reviews and direct measurements of ramin growth in the fields, it can be stated that growth of ramin plants is very slow with the highest annual height and diameter growth were $50.27 \mathrm{~cm}$ and $0.73 \mathrm{~cm}$, respectively. Therefore, it is necessary to find and to develop a technology to accelerate growth rate of the ramin plants. Application of mycorrhizal fungal inoculum is a promising technology, but their role in promoting the ramin growth and the needed cost must be tested and analyzed under various conditions of the peatswamp soils in Indonesia 


\section{CONCLUSIONS}

1. Moderate shading with light intensity from 55 to $60 \%$ and deep peat soil ranging from 3 to $4 \mathrm{~m}$ is an appropriate site characteristics to obtain a maximum annual increment of ramin. The highest annual height early growth was $50.27 \mathrm{~cm}$ found at Sei Bakau, West Kalimantan and the highest annual diameter early growth was $0.73 \mathrm{~cm}$ obtained at Rokan Hilir, Riau

2. The growth of ramin plants is very slow. Therefore, it is necessary to find and to develop a technology to accelerate growth rate of the ramin plants. Application of mycorrhizal fungal inoculum is a promising technology, but their role in promoting the ramin growth and the needed cost must be tested and analyzed under various conditions of the peatswamp soils in Indonesia.

\section{REFERENCES}

Alrasyid, H and I. Soerianegara. 1978. Pedoman enrichment planting Ramin (Gonystylus bancanan Kurz.). Laporan No.269. Lembaga Penelitian Hutan Bogor. 14 pp.

Anonymous. 2004. Kayu Ramin (Gonystylus spp.) masuk Appendix II dalam konvensi perdagangan internasional spesies flora dan fauna, CITES. Kronik, MKI Edisi VI.

Bastoni and A. Sianturi. 2000. Teknik penanaman dan pemeliharaan tanaman pengayaan (enrichment planting) pada hutan rawa gambut di Sumatera Selatan. Dalam. Prosiding Seminar Pengelolaan Hutan Rawa Gambut dan Ekspose Hasil Penelitian di Hutan Lahan Basah, Balai Teknologi Banjarbaru, Pusat Litbang Hutan dan Konservasi Alam. $35-36$.

Bastoni. 1999. Uji coba penanaman dan pemeliharaan tanaman pengayaan (enrichmentplanting) pada areal bekas tebangan hutan rawa gambut di Sumatera Selatan. Dalam. Prosiding Ekspose Hasil Penelitian dan Pengembangan Balai Teknologi Reboisasi, Palembang, Palembang. 43 - 59.

Daryono, H. 1996. Kondisi tegakan tinggal dan permudaan alam hutan rawa gambut setelah pembalakan dan teknik propagasinya. Dalam. Prosiding Diskusi Hasil-Hasil Penelitian dalam Menunjang Pemanfaatan Hutan yang Lestari, Cisarua. Pusat Litbang Hutan dan Konservasi Alam. 9 - 31.

Istomo. 1994. Hubungan antara komposisi, struktur dan penyebaran ramin (Gonystylus bancanus) dengan sifat-sifat tanah gambut (Studi kasus di areal HPH PT. Inhutani III Kalimantan Tengah). Tesis Program Pascasarjana IPB. Bogor.

Muin, A. 2004. Penanaman ramin (Gonystylus bancanus (Miq.) Kurz) pada areal bekas tebangan dengan inokulasi cendawan mikoriza arbuskula (CMA) dan pemupukan fosfat alam terhadap anakan di persemaian. Laporan penelitian Tahun III, Universitas 
Tanjungpura, Pontianak. 34 pp.

Muin, A. and T. Purwita. 2002. Intensitas cahaya untuk pemeliharaan permudaan alam dan penanaman ramin (Gonystylus bancanus (Miq.) Kurz) pada areal bekas tebangan eks HPH PT. Munsim, PT. Inhutani II. MKI, edisi VI: 9 - 13.

Riyanto, H. D. 1999. Pengaruh perlakuan silvikultur terhadap riap tegakan tinggal hutan alam rawa gambut di Jambi. Dalam Prosiding Ekspose Hasil Penelitian dan Pengembangan Balai Teknologi Reboisasi, Palembang, Palembang. 60 - 71.

Soediarto, R., R. Soetopo., R. I. Ardikusuma, and L. Darjadi. 1963. Keterangan-Keterangan Tentang Ramin (Gonystylus sp.). LPH dan LPHH. Bogor.

Soerianegara, I., Istomo., U. Rosalina, and I. Hilwan. 1996. Evaluasi dan penentuan system pengelolaan hutan ramin yang berazazkan kelestarian. Dalam. Rangkuman Penelitian Hibah Bersaing II. Fakultas Kehutanan. Institut Pertanian Bogor. 108 pp.

Soerianegera, I and R. H. M. J. Lemmens. 1994. Plant Resources of South-East Asia No. 5 (1) Timber trees: Major commercial timbers. Prosea. 221-230. 